\title{
Arbuscular mycorrhizal fungi in a coastal wetland in Yucatan,
} Mexico

This is an open access article distributed under the terms of the Creative Commons Attribution License, which permits unrestricted use, distribution, and reproduction in any medium, provided the original author and source are credited.

${ }^{1}$ Departamento de Ecología Tropical, Universidad Autónoma de Yucatán, Mérida, Yucatán, México.

${ }^{2}$ Unidad Multidisciplinaria de Docencia e Investigación, Facultad de Ciencias, Universidad Nacional Autónoma de México, Yucatán, México.

${ }^{3}$ Laboratorio de Micorrizas, Centro de Investigaciones en Ciencias Biológicas, Universidad Autónoma de Tlaxcala. Ixtacuixtla, Tlaxcala, México.

* Corresponding author: jaramos.zapata@gmail.com
Diana Fabián ${ }^{1}$, Patricia Guadarrama², Laura Hernadez-Cuevas ${ }^{3}$ and José Alberto Ramos-Zapata ${ }^{1 *}$

\section{Abstract}

Background: The wetlands provide important ecosystem services, but also represent a limiting environment for the organisms which are distributed there. However, these limiting factors can be overcome thanks to the biotic interactions established by the organisms.

Study species: Acoelorraphe wrightii is a palm inhabiting coastal wetlands and is found to be associated with arbuscular mycorrhizal fungi.

Question: The dynamic of the colonization by arbuscular mycorrhizal (AM) fungi of A. wrightii roots was evaluated, as well as the production of spores and the richness of AM fungal species in A. wrightii rhizosphere.

Study site: During the dry season (February-May), adult individuals of A. wrightii were selected in a wetland located in Yucatan, Mexico.

Methods: Roots and rhizospheric soil were collected from the A. wrightii individuals collected in order to evaluate mycorrhizal colonization of the roots and to estimate the amount and identity of spores.

Results: Colonization by AMF in A. wrightii roots was found between 24 and $67 \%$. Significant differences were found in percentage of colonization for the different months sampled. Number of spores showed no variation in the time, and 22 species of AMF were identified, the most represented being Glomeraceae.

Conclusions: The colonization of A. wrightii roots by AM fungi throughout all the sampling months suggests that the interaction is important for the plant. A high richness of AMF species in its rhizosphere was found with the presence of some exclusive species at the beginning and end of the rainy season.

Key words: Acoelorraphe wrightii, mycorrhizal colonization, richness of AMF species, spores, temporality.

\section{Resumen}

Antecedentes: Los humedales proveen de importantes servicios ecosistémicos pero también representan un ambiente limitante para los organismos que ahí se distribuyen. Las limitantes pueden ser superadas gracias a las interacciones bióticas que establecen.

Especie de estudio: Acoelorraphe wrightii es una palmera que habita los humedales costeros y se encuentra asociada con hongos micorrizógenos arbusculares.

Pregunta: Se evaluó la dinámica de la colonización por hongos micorrizógenos arbusculares (HMA) de las raíces de $A$. wrightii, la producción de esporas y la riqueza de especies de HMA en su rizósfera.

Sitio de estudio: Durante la temporada de sequía (febrero-mayo), individuos adultos de $A$. wrightii fueron seleccionados en un humedal localizado en Yucatán, México.

Métodos: Se colectaron raíces y suelo rizosférico de individuos seleccionados de A. wrightii, para evaluar la colonización micorrízica de las raíces y estimar la cantidad de esporas y su identidad.

Resultados: La colonización por HMA en las raíces de $A$. wrightii se encontró entre 24 y 67 \%. Se encontraron diferencias significativas en el porcentaje de colonización en los diferentes meses muestreados. El número de esporas no mostró una variación en el tiempo identificándose 22 especies de HMA, siendo la familia Glomeraceae la mejor representada.

Conclusiones: La colonización de las raíces de A. wrightii por hongos micorrizógenos arbusculares (HMA) en todos los meses de muestreo sugiere que la interacción es importante para la planta. Se encontró una alta riqueza de especies de HMA en su rizosfera presentándose algunas especies exclusivas en el inicio o término de la temporada de lluvias.

Palabras clave: Acoelorraphe wrightii, colonización micorrícia, esporas, riqueza de especies de HMA, temporalidad. 


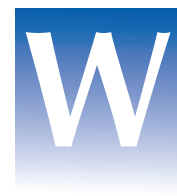

etlands provide a considerable number of ecosystem services, such as flood control, replenishment of subterranean water, stabilization of coasts by protecting them from the effects of storms, retention and export of sediments and nutrients, purification of water and also as important biodiversity reservoirs (Secretaría de la Convensión de Ramsar 2010) despite the challenging environmental conditions that characterize these environments, such as oxygen deficiency and accumulation of phytotoxins in the substrate, among others (Armstrong et al. 1991). Therefore, the organisms inhabiting these ecosystems have evolved different strategies to overcome the limitations of the environment (Bohrer et al.2004). The lack of oxygen in the soil of these ecosystems affects plant root growth and total anoxia can in fact inhibit root function (Armstrong et al. 1991). However, microorganisms inhabiting the rhizosphere may contribute to the functionality of the roots and to the ecology of the wetlands (Neori \& Agami 2016).

Interactions of the plants, through their roots, with soil microorganisms such as the arbuscular mycorrhizal (AM) fungi are known to increase plant tolerance to various types of environmental stress (Khan 1995), such as salinity (Evelin et al. 2009), drought (Augé 2001) and flooding (Stevens et al.2011). In the arbuscular mycorrhizal interaction, the fungi receive carbon from the host plants while providing them minerals nutrients (v.g., phosphorous, nitrogen) (Smith \& Read 2008), since the nutritional and physiological status in the host plants are improved they may be more resistant to harsh environmental conditions (Ievinsh 2006, Solaiman et al. 2014).

Arbuscular mycorrhizal interaction has already been reported in wetland plants of different sites (v.g., Bâ \& Rivera-Ocasio 2015, Caravaca et al. 2005, Turner \& Friese 1998, Turner et al. 2000, also see review of Xu et al. 2016); nevertheless, the ecological repercussions of this mutualistic association have not been clearly demonstrated in these ecosystems (Neori \& Agami 2016, Xu et al.2016).

Moreover, the environmental conditions present in the wetlands also have an effect on the AM fungi due to the fact that, given the environmental heterogeneity ( $v . g$., salinity, anoxic conditions), the richness of AM species can vary widely (Juniper \& Abbott 1993, Miller \& Bever 1999), and colonization of the plant roots by AM fungi can be affected by periods of flooding, resulting in increased or reduced colonization of the roots (see Vallino et al. 2014, Xu et al. 2016), thus it has been demonstrated that a large number of plant species in the wetlands are interacting with the AM fungi (see Wang et al. 2015, Xu et al. 2016).

Acoelorraphe wrightii $\mathrm{H}$. Wendl. (Arecaceae, common name: palmetto palm and locally known as tasiste) is a palm dominating in wetlands where flooding is temporary (Quero-Rico \& Flores 2004). This species has previously been reported to associate with AM fungi (Fisher \& Jayachandran 2008) and tolerates flooding for extended periods (> 6 months; Ocaña \& Lot 1996). In the wetlands of the Yucatan Peninsula, it is common to find plant associations where the palm A. wrightii is the dominant species.

Research on wetland AM fungi has been scarce in Mexico, for this reason the objective of this study was to quantify the colonization by AM fungal structures (hyphae, vesicles, spores and coils) in the roots of Acoelorraphe wrightii during the dry season (from February to May), as well as to estimate the variation during the beginning and end of the dry season in density, diversity and viability of the AM fungi spores collected from its rhizosphere. The hypothesis of this work is that $A$. wrightii roots will present colonization by AM fungi which will vary during dry season (because of flooding fluctuations) and, due to the environmental heterogeneity of the wetland, a high richness in AMF species is expected to be found in its rhizosphere.

\section{Materials and methods}

Laura Hernández-Cuevas performed the identification of arbuscular mycorrhizal fungi, and analyzed the data. José Alberto Ramos Zapata designed the field work, performed the field work, analyzed the data, and wrote the manuscript.

Study site. The study site is in the State Reserve Ciénegas y Manglares of the northern coast

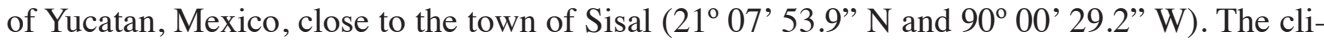
mate of the zone is warm dry Bso(h')w"( $\left.\mathrm{x}^{\prime}\right) \mathrm{i}$, according to the Köppen classification, modified by García (1973) with a precipitation/evapotranspiration ratio of less than 22.9, predominant summer rain (June-September), but with over $10 \%$ the total annual rain falling in winter (December-January). There is an intra-estival drought, and the mean annual temperature is around $22{ }^{\circ} \mathrm{C}$ (Orellana et al. 1999). 
The soil type is rendzina, dark, with a depth ranging between $10-50 \mathrm{~cm}$ (González-Medrano 2003). Due to the presence of interstitial water, the average salinity of the site is $2.7 \%$ o and the mean $\mathrm{pH}$ is 6.6 , while for the surface water, the salinity is $1.26 \%$ and the $\mathrm{pH}$ is 6.7 . In the site, there are four abundant plant species: A. wrightii (Arecaceae), Cladium jamaicense (Cyperaceae), Scleria bracteata (Cyperaceae), and Rhynchospora colorata (Cyperaceae), with $A$. wrightii and $S$. bracteata dominating. When A. wrightii dominates the vegetation, the resulting association is known locally as a "tasistal" or floodable palm grove (Martínez \& Galindo-Leal 2002).

Sampling design. An area of $100 \times 100 \mathrm{~m}(30 \%$ of the wetland fragment) was selected and the presence of Acoelorraphe wrightii was identified; 19 individuals were selected at random, but each one complying with the following conditions: presence of inflorescences and a height between 2 and 2.5 meters, the aim being to reduce the effect of the variability produced by the age and physiological state of the plant. These were marked and samples were taken from their roots or rhizosphere every month from February to May 2007 (for root colonization) and in February and July (for spore extraction), during the dry season (flooded conditions at the beginning of the dry season), coinciding with the flowering season of the palm.

Mycorrhizal colonization. Fine roots $(<2 \mathrm{~mm}$ in diameter) were taken from nine of the marked individuals (Brundrett et al. 1996) and these were washed, labeled and dyed (with Trypan blue) following the procedure of Phillips \& Hayman (1970), modified by Hernández-Cuevas et al. (2008). Two to four permanent slides (containing 10 to 12 root fragments each) were prepared with the dyed roots and total mycorrhizal colonization as well as per structure (hyphae, vesicles, spores and coils) were quantified according to the method of McGonigle et al. (1990), monitoring at least 100 optical fields at 100x magnification in a Nikon optical microscope. During the first sampling period (February), it was not possible to collect roots from all the 19 individuals selected due to the prevailing flood conditions which made it impossible to be sure that the roots collected belonged to the marked palms; therefore, we decided to take root samples only of nine individuals, the roots of the same individuals were collected during all sampling periods (February to May).

Spores of arbuscular mycorrhizal fungi. In order to isolate the spores present in the rhizosphere of Acoelorraphe wrightii, soil samples were taken around the 19 randomly selected individuals at the beginning and end of the dry season (February and July 2007). Around each selected palm tree, four soil samples were taken at a depth of up to $10 \mathrm{~cm}$ and combined to a final sample of $500 \mathrm{~g}$ of rhizospheric soil. Extraction of the spores was conducted on 50 $\mathrm{g}$ of dry soil using the wet-sieving method of Gerdemann \& Nicolson (1963), modified by Hernández-Cuevas et al. (2008), using a set of sieves from 600 to 45 micrometers. Isolated spores were collected in semi-permanent preparations with polyvinyl alcohol (PVLG) and Melzer reagent for observation under an optical microscope (45X) and determination of the AM fungi species. Live and dead spores were quantified; spores were considered live when they appeared without damage on spore walls and presented cytoplasmic content, but were considered dead if the spore walls were damaged or if the spore was parasitized and had no cytoplasmic content.

To identify the AM fungi species, the morphological characteristics of the spores were observed: size, color, wall characteristics, number of strata, presentation of germination structures, subtending hypha and the occurrence of a reaction to the Melzer reagent. The AM fungi were then identified considering the species descriptions of the International Culture Collection of (Vesicular) Arbuscular Mycorrhizal Fungi (INVAM) web page (https://invam.wvu.edu/) the Manual for the identification of VA mycorrhizal fungi (Schenk \& Pérez 1988) and the web page (http://www.zor.zut.edu.pl/Glomeromycota/Taxonomy.html). The system proposed by Schüßler \& Walker (2010) was utilized for the classification. In order to avoid mistakes during the identification process, only spores with cytoplasmic content and with clear morphological characters were employed to assign identity. Recently, the use of molecular tools for identifying communities of AM fungi has been development. However, since there is still absence of uni- 
formity regarding the AMF-specific primer system that best reflect the diversity of AM fungi in a community (Kohout et al. 2014), we decided to use the morphological characterization since we believe this approach remains valid to reach the aim of this study, as has been pointed out by other authors (v.g., Oehl et al. 2004, Luo et al. 2016).

Statistical analysis. For root colonization and spore number analysis we used the PROC MIXED method for repeated measures with the compound symmetry structure of covariance and type III sums of squares, considering the palm identity as random effect and month as fixed effect; since all data showed normality and homogeneity of variances these were not transformed, when significant effect of main factor differences was determined on pre-planned contrast. We used Statistical Analysis System (SAS) software 9.3.

\section{Results}

Mycorrhizal colonization. Mycorrhizal colonization of type Arum (intercellular hyphae without intracellular coils) was recorded in the roots of all of the sampled individuals of Acoelorraphe wrightii. Only three types of fungal structures were observed: hyphae, vesicles and spores. The percentage of total colonization differed significantly $\left(F_{3,24}=7.76, p<0.05\right.$, Figure 1a) among sampling times, with the months of February and April presenting the highest and lowest percentages of colonization, respectively. Significant differences were found among sampling times in terms of the percentage of colonization by hyphae $\left(F_{3,24}=8.57 p<0.05\right)$ (Figure 1b),
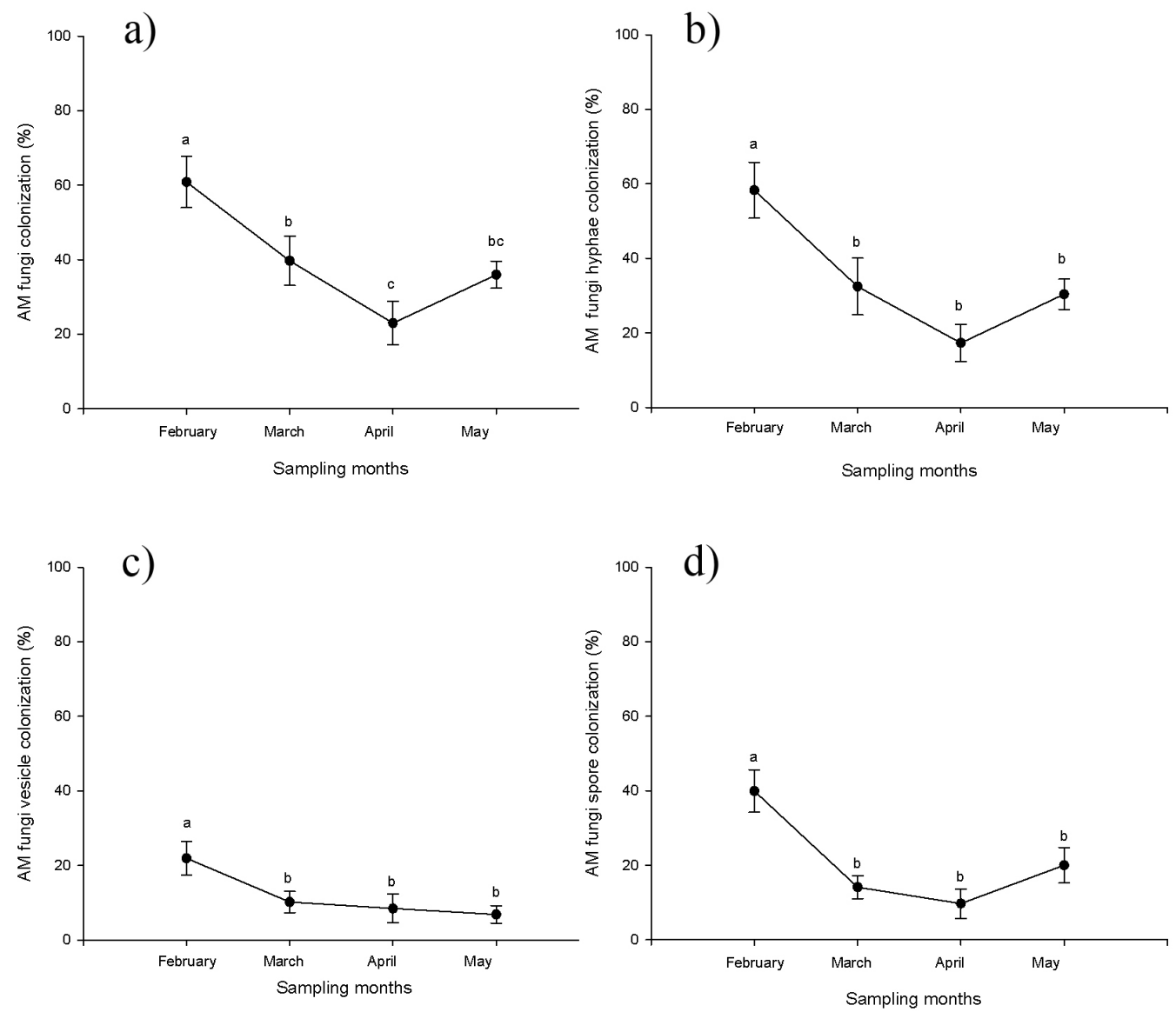

Figure 1. Percentage of mycorrhizal colonization in different sampling months (dry season February-May) in a wetland, where a) mean $( \pm$ S.E.) total; b) mean $( \pm$ S.E.) by hyphae; c) mean $( \pm$ S.E.) by vesicles; d) mean $( \pm$ S.E. $)$ by spores. Means accompanied by the same letter do not differ significantly at $p<0.05$. 
Table 1. Family and species of arbuscular mycorrhizal fungi and the seasons in which they were observed: beginning of dry season (February) and beginning of rainy season (July).

\begin{tabular}{|c|c|c|c|}
\hline Family & Species & $\begin{array}{l}\text { Beginning } \\
\text { of dry } \\
\text { season }\end{array}$ & $\begin{array}{c}\text { Beginning } \\
\text { of rainy } \\
\text { season }\end{array}$ \\
\hline \multirow[t]{11}{*}{ Glomeraceae } & $\begin{array}{l}\text { Funneliformis geosporum (T.H. Nicolson \& Gerd.) } \\
\text { C. Walker \& A. Schußler }\end{array}$ & * & * \\
\hline & $\begin{array}{l}\text { Funneliformis verruculosum (Blaszk.) C. Walker \& } \\
\text { A. Schußler }\end{array}$ & * & * \\
\hline & $\begin{array}{l}\text { Rhizophagus clarus(T.H. Nicolson \& N.C. Schenck) } \\
\text { C. Walker \& A. Schüßler }\end{array}$ & & * \\
\hline & $\begin{array}{l}\text { Rhizophagus intraradices (N.C. Schenck \& G.S. Sm.) } \\
\text { C. Walker \& A. Schüßler }\end{array}$ & & * \\
\hline & Rhizophagus fasciculatus (Taxt.) C. Walker \& A. Schußler & * & \\
\hline & Sclerocystis sinuosa Gerd. \& B.K. Bakshi & & * \\
\hline & Sclerocystis rubiformis Gerd. \& Trappe & * & * \\
\hline & Glomus microaggregatum Koske, Gemma \& P.D. Olexia & * & * \\
\hline & Glomus ambisporum G.S. Sm. \& N.C. Schenck & & * \\
\hline & Glomus microcarpum Tul. \& C. Tul & & * \\
\hline & $\begin{array}{l}\text { Septoglomus constrictum (Trappe) Sieverd., G.A. } \\
\text { Silva \& Oehl }\end{array}$ & & * \\
\hline \multirow[t]{2}{*}{ Claroideoglomeraceae } & $\begin{array}{l}\text { Claroideoglomus claroideum (N.C. Schenck \& G.S. } \\
\text { Sm.) C. Walker \& A. Schüßler }\end{array}$ & * & * \\
\hline & $\begin{array}{l}\text { Claroideoglomus etunicatum (W.N. Becker \& Gerd.) } \\
\text { C. Walker \& A. Schußler }\end{array}$ & * & * \\
\hline Diversisporaceae & $\begin{array}{l}\text { Diversispora eburnea (L.J. Kenn, J.C. Stutz \& J.B. Morton) } \\
\text { C. Walker \& A. Schüßler. }\end{array}$ & * & * \\
\hline \multirow[t]{2}{*}{ Gigasporaceae } & $\begin{array}{l}\text { Scutellospora heterogama (T.H. Nicolson \& Gerd.) } \\
\text { C. Walker \& F.E. Sanders }\end{array}$ & * & \\
\hline & Gigaspora decipiens I.R. Hall \& L.K. Abbott. & & $*$ \\
\hline \multirow[t]{4}{*}{ Acaulosporaceae } & Acaulospora morrowiae Spain \& N.C. Schenck & * & * \\
\hline & Acaulospora scrobiculata Trappe & & * \\
\hline & $\begin{array}{l}\text { Acaulospora kentinensis(C.G. Wu \& Y.S. Liu) } \\
\text { Kaonongbua, J.B. Morton \& Bever }\end{array}$ & * & * \\
\hline & $\begin{array}{l}\text { Acaulospora colombiana (Spain \& N.C. Schenck) } \\
\text { Kaonongbua, J.B. Morton \& Bever }\end{array}$ & & * \\
\hline Paraglomeraceae & Paraglomus occultum (C. Walker) J.B. Morton \& D. Redecker & & * \\
\hline Entrophosporaceae & $\begin{array}{l}\text { Entrophospora infrequens (I.R. Hall) R.N. Ames } \\
\text { \& R.W. Schneid. }\end{array}$ & * & \\
\hline
\end{tabular}

vesicles $\left(F_{3,24}=3.46, p<0.05\right)$ (Figure $\left.1 \mathrm{c}\right)$ and spores $\left(F_{3,24}=9.42, p<0.005\right)$ (Figure 1d). February presented the highest percentage of colonization for all structures while April presented the lowest percentage of colonization for hyphae and spores. The lowest percentage of colonization for vesicles was observed in May (Figure 1c).

Spores of arbuscular mycorrhizal fungi. A total of 22 species of AM fungi were found in the rhizosphere of $A$. wrightii (Table 1). These 22 species belonged to seven families and 12 genera, of the seven families of AMF recorded, Glomeraceae accounted for $50 \%$ of the species, Acaulosporaceae for $18 \%$, Claroideoglomeraceae and Diversisporaceae each accounted for $9 \%$, while Gigasporaceae, Paraglomeraceae and Entrophosporaceae each accounted for $4.5 \%$. A total of 12 species were found at the beginning of the dry season (February) and 19 at the beginning of the rainy season (July) (Table 1). 
Figure 2. Mean number $( \pm S$ E.) of live and dead spores in $50 \mathrm{~g}$ of soil, in the months of February and July. Means accompanied by the same letter do not differ significantly at $p<0.05$.

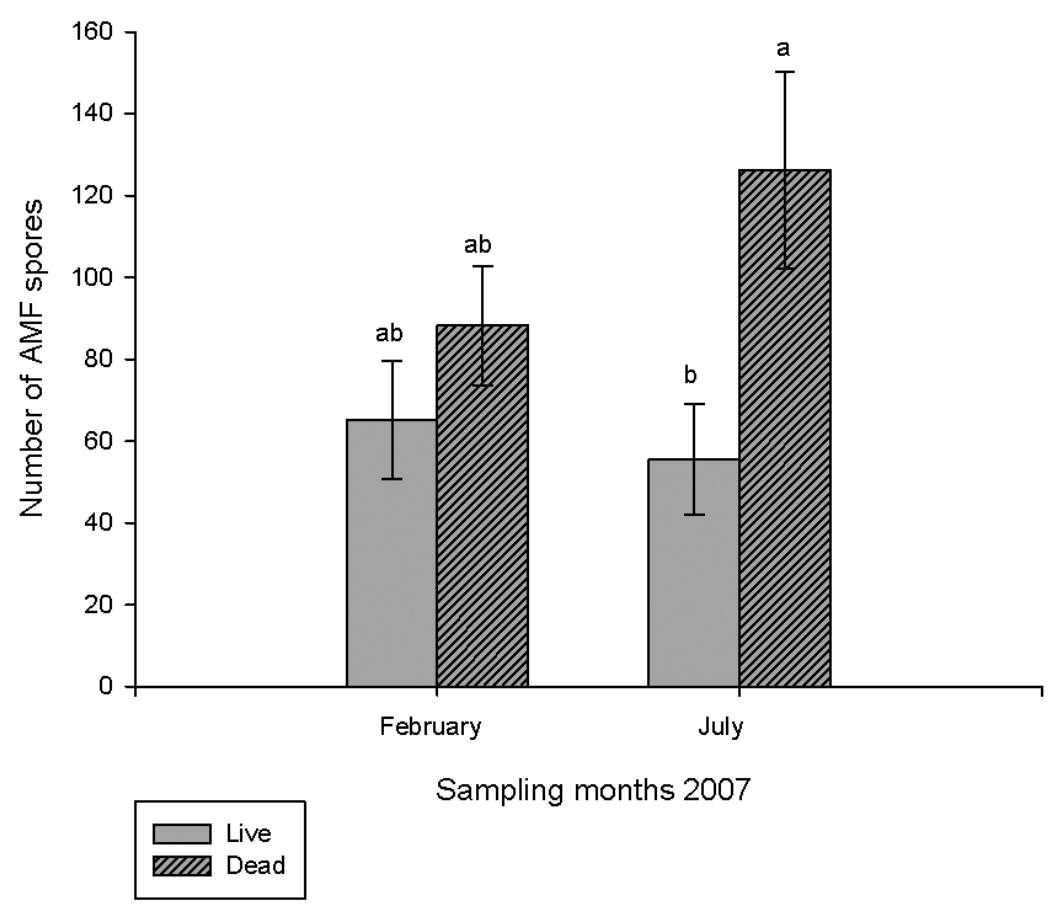

The average total number of spores (live and dead) in $50 \mathrm{~g}$ of soil was 126 in February and 211 in July; however, no significant differences were found among sampling months. When comparing the number of live and dead spores there was no significant difference in February, whereas in July there was, on average, twice as many dead spores as live $\left(F_{1,18}=7.08, p<0.001\right)$ (Figure 2).

\section{Discussion}

Generally speaking, the results show that during the period of this study, Acoelorraphe wrightii roots presented mycorrhizal colonization and a total of 22 species of AMF were found in its rhizosphere, although the majority of the spores were damaged. The working hypothesis was supported in the sense that all the individuals analyzed presented arbuscular mycorrhizal colonization in their roots and that this fluctuated temporally. Moreover, a high richness of AM fungi species was found, which coincides with the expected results. The fluctuation in colonization values and number of spores is discussed below.

Acoelorraphe wrightii present Arum-type colonization, as has been reported in other palm species, such as Serenoa repens, Cocothrinax argentata, Pseudophoenix sargentii, Sabal palmetto and Thrinax morrisii (Fisher \& Jayachandran 1999, 2005). The type of colonization is influenced by both the identity of the host plant (Smith \& Smith 1997) and fungi (Dickson et al. 2007), as well as the AM fungi efficiency which differs according to the plant species and the colonizing fungi (Cavagnaro et al. 2001, Mohammadi et al. 2008).

Intercellular hyphae, vesicles and spores typical of the Arum colonization type were observed in the roots of $A$. wrightii (Cavagnaro et al. 2001), but no arbuscules were observed. The absence of arbuscules in our observation may be due to their ephemeral nature (Smith \& Read 2008) and low frequency in field samples; but particularly in wetland plants mycorrhized roots commonly present a reduced number or even total absence of arbuscules (v.g., Dolinar et al. 2016, Khan 1993, Sengupta \& Chaudhuri 2002). Absence of arbuscules in mycorrhizal roots has been explained as an effect of flooding (Dolinar et al. 2016, Wang et al. 2016) this may support the results observed in the present work. The absence of arbuscules at some moment of interaction could be interpreted as an inactive mycorrhiza (Dolinar et al. 2016, but see Vallino et al. 2014) or that the mutualistic exchange of nutrients is absent (Wang et al. 2016) at that particular moment; nevertheless, to test any of these hypotheses a physiological experiment is needed. 
Extensive evidence suggests that arbuscular mycorrhizal (AM) root colonization declines during extended periods of flooding (v.g., Dolinar et al. 2016, Miller 2000, Ray \& Inouye 2006, Stevens et al. 2011, Vallino et al. 2014, but see Xu et al. 2016). A. wrightii presents fluctuations in the percentage of root colonization associated with the sampling month, however the highest percentage of root colonization was found in February (beginning of the dry season), while the lowest was presented when the site was no longer flooded (April and May); this may be because at the end of the dry season the soil drought may have limited fungal development, these results are in agreement with Bohrer et al. (2004) who found the highest mycorrhizal colonization level during the period of highest water table which coincides with the production of new roots in the plants. It has been demonstrated that AM colonization of the roots is also influenced by the physiological stage of the plant, for example, Carvalho et al. (2001) found that salt marsh plants presented greater mycorrhizal colonization during the periods of growth and flowering, independently of the abiotic characteristics. Oliveira et al. (2001) found that AM colonization in Phragmites australis of temporally flooded soils increased prior to flowering; therefore, it can be suggested that AM root colonization of wetland plants, as well as in other environments may be influenced by the phenology of the host plant (Bohrer et al. 2004, Xu et al. 2016). Nonetheless, because this work covered only the flowering stage of A. wrightii, we cannot form a conclusion with reference to the main factor affecting AM colonization. Further research on seasonal mycorrhizal colonization of A. wrightii roots, including phenology of the plant, is required to understand the role of biotic and abiotic factors on AM root colonization seasonality.

The average number of live spores found in $50 \mathrm{~g}$ of soil was between 56 and 70, a level that can be considered low compared to that reported by Jayachandran \& Shetty (2003) in the Florida everglades, where 936 to 6,214 spores were found in $50 \mathrm{~g}$ of soil (however, the authors did not report if all the spores were live). It has been reported that the number of spores can be influenced by the characteristics of the soil and by the structure of the vegetal community (Hetrick 1984, Janos 1980). This difference can be attributed to the fact that the vegetal community of the site where the study of Jayachandran \& Shetty (2003) was conducted was dominated by six plant species, while in this study site the plant community is dominated by only two species: Acoelorraphe wrightii and Scleria bracteata and this could have influenced the low number of spores found.

The number of spores found in the rhizosphere of Acoelorraphe wrightii change significantly over time. We found the highest number of spores at the onset of the rainy season, in July, which may have been due to dispersion of the AM fungal spores by wind (Warner et al. 1987). This study supports the data reported by Ramos-Zapata et al. (2011) in a tropical coastal dune system, where the number of spores was greater during the rainy season because flooding can transport spores to less elevated sites and also coincides with Xu et al. (2016) who mention that, in the wetlands, many of the AM fungi propagules are transported by water and can remain active in the soil once the flooding is over.

The species richness of AM fungi in the tasistal is high, compared to that reported for wetland ecosystems. For example: Sengupta \& Chaudhuri (2002) report seven species of AM fungi (predominating species of the genera Glomus and Gigaspora) in mangroves from the Ganges river; Choudhury et al. (2010) found 18 species of AM fugi in the rhizosphere of 23 species of wetland plants in Assam, India; and Wang et al. (2015) report six species of AM fungi (of the genera Glomus and Acaulospora) in two mangroves of southern China. The high AM fungi richness found in the present work, could be influenced by the surrounding vegetation, since the study site is surrounded by petens (islands of arboreal vegetation that include species of tropical medium sub-deciduous forest as well as mangrove elements) and the spores of these neighboring sites could move into this site, as explained above.

Another reason which can explain the high AM fungal species richness found in this work could be the high environmental heterogeneity. Flooding has been recognized as a driving force for heterogeneity and dynamics of wetlands (Day et al. 1988, Keddy 2010, Simões et al. 2013, but see Brinson 1993), affecting the mycorrhizal interactions and distribution of AM fungi that colonize the roots; for example, some AM fungi prefer less anoxic soils and the fungal hyphae and spores are sensitive to low redox potential (Deepika \& Kothamasi 2015, Neori \& Agami 2016, Wang et al.2015, Wolfe et al.2007). These environmental gradients might provoke a high 
species richness because species that can thrive under extremely harsh conditions and those that prefer a less challenging environment can actually coexist; consequently, this high environmental heterogeneity may complete the above explanation regarding the richness of species found in the present study.

Temporality plays an important role in terms of changes in the richness of AM fungal species within the site. Of the species found at the beginning of the rainy season, $47 \%$ were exclusive to that season (Rhizophagus clarus, Rhizophagus intraradices, Sclerocystis sinuosa, Glomus ambisporum, Glomus microcarpum, Septoglomus constrictum, Gigaspora decipiens, Acaulospora scrobiculata, Acaulospora colombiana and Paraglomus occultum); while at the beginning of the dry season only three exclusive species ( $25 \%$ ) were recorded, (Rhizophagus fasciculatus, Scutellospora heterogama and Entrophospora infrequens). This could be due to the process described previously in which the rain may transport spores that originate in neighboring sites and, in the absence of rain in February; the spores are not being successfully transported at that time.

This is the first study to explore mycorrhizal arbuscular interaction in a coastal wetland of Mexico. The high species richness found in the rhizosphere of A. wrightii may be a result of different dispersion mechanisms of AM fungi, which, as has been reported before by other authors, can remain viable and establish the interaction with A. wrightii roots. The AM root colonization in $A$. wrightii, present in all the sampling months suggests that the species of AM fungi isolated can be found colonizing the root system; and that this is important for the plant, at least in the physiological stage (flowering) which was covered in this work, due to the different advantages this can provide, such as capture of nutrients and resistance to flooding. Further investigation is required on the colonization behavior in different physiological stages. It is important to produce more information in terms of the AM fungal community in ecosystems such as the wetlands, since these cannot be ignored in the management practiced in these ecosystems.

\section{Acknowledgements}

Thanks go to Uriel Solís Rodríguez, Luis Salinas Peba and Denis Marrufo for their support in collecting the field samples and laboratory processing.

\section{Literature cited}

Augé R. 2001. Water relations, drought and vesicular-arbuscular mycorrhizal symbiosis. Mycorrhiza 11: 3-42. DOI: $10.1007 / \mathrm{s} 005720100097$

Armstrong W, Justin SHFW, Beckett PM, Lythe S. 1991. Root adaptation to soil waterlogging. Aquatic Botany 39: 57-73. DOI: 10.1016/0304-3770(91)90022-W

Bâ AM, Rivera-Ocasio E. 2015. Genetic diversity and functional traits of Pterocarpus officinalis Jacq. associated with symbiotic microbial communities in Caribbean swamp forests in relation to insular distribution, salinity and flooding. Wetlands 35: 433-442. DOI: 10.1007/s13157-015-0651-5

Bohrer KE, Friese CF, Amon JP. 2004. Seasonal dynamics of arbuscular mycorrhizal fungi in differing wetland habitats. Mycorrhiza 14: 329-337. DOI: 10.1007/s00572-004-0292-7

Brinson MM. 1993. Changes in the functioning of wetlands along environmental gradients. Wetlands 13: 65-74. DOI: $10.1007 / \mathrm{BF} 03160866$

Brundrett MC, Bougher N, Dell B, Grove T, Malajczuk N. 1996. Working with mycorrhizas in forestry and agriculture. Canberra: ACIAR.

Caravaca F, Alguacil MM, Torres P, Roldán A. 2005. Microbial activities and arbuscular mycorrhizal fungi colonization in the rhizosphere of the salt marsh plant Inula crithmoides L. along a spatial salinity gradient. Wetlands 25: 350-355. DOI: 10.1672/11

Carvalho LM, Caçador I, Martins-Loução M. 2001. Temporal and spatial variation of arbuscular mycorrhizas in salt marsh plants of the Tagus estuary (Portugal). Mycorrhiza 11: 303-309. DOI 10.1007/s00572001-0137-6

Cavagnaro TR, Gao LL, Smith FA, Smith SE. 2001. Morphology of arbuscular mycorrhizas is influenced by fungal identity. New Phytologist 151: 469-475. DOI: 10.1046/j.0028-646x.2001.00191.x

Choudhury B, Kalita MC, Azad P. 2010. Distribution of arbuscular mycorrhizal fungi in marshy and shoreline vegetation of Deepar Beel Ramsar Site of Assam, India. World Journal of Microbiology \& Biotechnology 26: 1965-1971. DOI: 10.1007/s11274-010-0377-8

Day FP, West SK, Tupacz EG. 1988. The influence of ground-water dynamics in a periodically flooded ecosystem, the great dismal swamp. Wetlands 8: 1-13. DOI: 10.1007/BF03160805 
Deepika S, Kothamasi D. 2015. Soil moisture-a regulator of arbuscular mycorrhizal fungal community assembly and symbiotic phosphorus uptake. Mycorrhiza 25: 67-75. DOI:10.1007/s00572-014-0596-1

Dickson S, Smith FA, Smith SE. 2007. Structural differences in arbuscular mycorrhizal symbioses: more than 100 years after Gallaud, where next? Mycorrhiza 17: 375-393. DOI: 10.1007/s00572-007-0130-9

Dolinar N, Regvar M, Abram D, Gaberščik A. 2016. Water-level fluctuations as a driver of Phragmites australis primary productivity, litter decomposition, and fungal root colonisation in an intermittent wetland. Hydrobiologia 774: 69-80. DOI:10.1007/s10750-015-2492-x

Evelin H, Kapoor R, Giri B. 2009. Arbuscular mycorrhizal fungi in alleviation of salt stress: a review. Annals of Botany 104: 1263-1280. DOI:10.1093/aob/mcp251

Fisher JB, Jayachandran K. 1999. Root structure and arbuscular mycorrhizal colonization of the palm Serenoa repens under field conditions. Plant and Soil 217: 229-241. DOI: 10.1023/A:1004576001334

Fisher JB, Jayachandran K. 2005. Presence of arbuscular mycorrhizal fungi in South Florida native plants. Mycorrhiza 15: 580-588. DOI: 10.1007/s00572-005-0367-0

Fisher JB, Jayachandran K. 2008. Beneficial role of arbuscular mycorrhizal fungi on Florida native palms. Palms 52: 115-125.

Quero-Rico H, Flores SJ. 2004. Arecaceae de la Peníncula de Yucatán (Taxonomía, Florística y Etnobotánica). Etnoflora Yucatanense, Yucatán: Universidad Autónoma de Yucatán.

García E. 1973. Modificaciones al sistema de clasificación climática Koeppen. (para adaptarlo a las condiciones de la República Mexicana). Instituto de Geografía, Universidad Nacional Autónoma de México.

Gerdemann JW, Nicolson TH. 1963. Spores of mycorrizal Endogone species extracted from soil by wet sieving and decanting. Transactions of the British Mycological Society 46: 234-244.

González-Medrano F. 2003. Las comunidades vegetales de México. Propuesta para la unificación de la clasificación y nomenclatura de la vegetación de México. Ciudad de México: INE-SEMARNAT.

Hernández-Cuevas L, Guadarrama P, Sánchez-Gallen I, Ramos-Zapata J. 2008. Micorriza arbuscular. Colonización intrarradical y extracción de esporas del suelo. In: Álvarez-Sánchez J, Monroy-Ata A, eds. Técnicas de Estudio de las Asociaciones Micorrízicas y sus Implicaciones en la Restauración. Ciudad de México: Las prensas de ciencias UNAM, 1-15.

Hetrick BAD. 1984. Ecology of VA mycorrhizal fungi. In: Powell, CL, Bagyaraj DJ, eds. VA Mycorrhizae. Boca Raton: CRC Press, 35-55.

Ievinsh G, 2006. Biological basis of biological diversity: physiological adaptations of plants to heterogeneous habitats along a sea coast. Acta Universitatis Latviensis 710: 53-79.

INVAM Internacional Culture Collection of (Vesicular) Arbuscular Mycorrhizal Fungi. <https://invam. wvu.edu/> (accessed February 21, 2016).

Janos DP. 1980. Vesicular-arbuscular mycorrhizae affect lowland tropical rain forest plant growth. Ecology 61: 151-162. DOI: $10.2307 / 1937165$

Jayachandran K, Shetty KG. 2003. Growth response and phosphorus uptake by arbuscular mycorrhizae of wet prairie sawgrass. Aquatic Botany 76: 281-290. DOI: dx.doi.org/10.1016/s0304-3770(03)00075-5

Juniper S, Abbott L. 1999. Vesicular-arbuscular mycorrhizas and soil salinity. Mycorrhiza 4: 45-57. DOI: 10.1007/BF00204058

Keddy PA. 2010. Wetland ecology, principles and conservation. Cambridge: Cambridge University Press.

Khan AG. 1993. Vesicular arbuscular mycorrhizae (VAM) in aquatic trees of New South Wales, Australia, and their importance at land-water interface. In: Gopal B, Hllbricht-Ilkowska A, Wetzel RG, eds. Wetlands and Ecotones: Studies on Land-Water Interactions. New Delhi: National Institute of Ecology, 173-180.

Khan AG. 1995. Effects of various soil environmental stresses on the occurrence, distribution and effectiveness of arbuscular mycorrhizae. Biotropia-The Southeast Asian Journal of Tropical Biology 8 : 39-44. DOI: 10.11598/btb.1995.0.8.117

Kohout P, Sudová R, Janousková M, Ctvrtlíková M, Hejda M, Pánková H, Slavíková R, Stajerová K, Vosátka M, Sýkorová Z. 2014. Comparison of commonly used primer sets for evaluating arbuscular mycorrhizal fungal communities: Is there a universal solution? Soil Biology and Biochemistry 68: 482493. DOI: $10.1016 /$ j.soilbio.2013.08.027

Luo X, Su X, Cui J, Lou Y, Li R, Luo X, Zeng Y, Xu Y, Dong J. 2016. Biodiversity of arbuscular mycorrhizal fungi in the drawdown zone of the Three Gorges Reservoir under different fertilization histories. Ecological Research 31: 407-416. DOI: 10.1007/s11284-016-1356-9

Martínez E, Galindo-Leal C. 2002. La vegetación de Calakmul, Campeche, México: clasificación, descripción y distribución. Boletín de la Sociedad Botánica de México 71: 7-32. DOI: 10.17129/botsci.1660

McGonigle TP, Miller MH, Evans DG, Fairchild GL, Swan JA. 1990. A new method which gives and objective measure of colonization of roots by vesicular arbuscular mycorrhizal fungi. New Phytologist 115: 495-501. DOI: 10.1111/j.1469-8137.1990.tb00476.x

Miller SP. 2000. Arbuscular mycorrhizal colonization of semi-aquatic grasses along a wide hydrologic gradient. New Phytologist 145: 145-155. DOI: 10.1046/j.1469-8137.2000.00566.x 
Miller SP, Bever JD. 1999. Distribution of arbuscular mycorrhizal fungi in stands of the wetland grass Panicum hemitomon along a wide hydrologic gradient. Oecologia 119: 586-592. DOI: 10.1007/ s004420050823

Mohammadi E, Rezae R, Prasad R, Varma A. 2008. Mycorrhizal Fungi: What We Know and What Should We Know? In: Varma A, ed. Mycorrhiza State of the Art, Genetics and Molecular Biology, Eco-Function, Biotechnology, Eco-Physiology, Structure and Systematics. Berlin: Springer-Verlag, 3-27.

Neori A, Agami M. 2016. The Functioning of Rhizosphere Biota in Wetlands- a Review. Wetlands 1-19. DOI 10.1007/s13157-016-0757-4

Ocaña D, Lot A.1996. Estudio de la vegetación acuática vascular del sistema fluvio-lagunar-deltaico del río Palizada, en Campeche, México. Anales del Instituto de Biología 67: 303-327.

Oehl F, Sieverding E, Mäder P, Dubois D, Ineichen K, Boller T, Wiemken A. 2004. Impact of long-term conventional and organic farming on the diversity of arbuscular mycorrhizal fungi. Oecologia 138: 574-583. DOI: 10.1007/s00442-003-1458-2

Oliveira RS, Dodd JC, Castro PML. 2001. The mycorrhizal status of Phragmites australis in several polluted soils and sediments of an industrialised region of Northern Portugal. Mycorrhiza 10: 241-247. DOI: $10.1007 / \mathrm{s} 005720000087$

Orellana R, Balam-Ku M, Bañuelos-Robles I, García E, González-Iturbe JA, Herrera-Cetina F, VidalLópez J. 1999. Evaluación climática. In: García de Fuentes A, Córdoba J, Ordóñez Y, Chico Ponce de León P, eds. Atlas de Procesos Territoriales de Yucatán. Mérida: Universidad Autónoma de Yucatán, 163-182.

Phillips JM, Hayman DS. 1970. Improved procedures for clearing roots and staining parasitic and vesicular-arbuscular mycorrhizal fungi for rapid assessment of infection. Transactions of the British Mycological Society 55: 158-160. DOI: 10.1016/S0007-1536(70)80110-3

Secretaría de la Convensión de Ramsar. 2010. Asignación y manejo de los recursos hídricos: Lineamientos para la asignación y el manejo de los recursos hídricos a fin de mantener las funciones ecológicas de los humedales. Manuales Ramsar para el uso racional de los humedales. Gland, Suiza: Secretaría de la Convención de Ramsar.

Ramos-Zapata J, Zapata R, Ortiz-Díaz JJ, Guadarrama P. 2011. Arbuscular mycorrhizas in a tropical coastal dune system in Yucatan, Mexico. Fungal Ecology 4: 256-261. DOI: 10.1016/j.funeco.2010.12.002

Ray AM, Inouye RS. 2006. Effects of water-level fluctuations on the arbuscular mycorrhizal colonization of Typha latifolia L. Aquatic Botany 84: 210-216. DOI: 10.1016/j.aquabot.2005.10.005

Schenk NC, Pérez Y. 1988. Manual for the Identification of VA Mycorrhizal Fungi. Gainesville: University of Florida.

Schüßler A, Walker C. 2010. The Glomeromycota A species list with new families and new genera. Gloucester, England.

Sengupta A, Chaudhuri S. 2002. Arbuscular mycorrhizal relations of mangrove plant community at the Ganges river estuary in India. Mycorrhiza 12: 169-174. DOI: 10.1007/s00572-002-0164-y

Simões NR, Dias JD, Leal CM, Braghin LSM, Lansac-Tõha FA, Bonecker CC. 2013. Floods control the influence of environmental gradients on the diversity of zooplankton communities in a neotropical floodplain. Aquatic Sciences 75: 607-617. DOI: 10.1007/s00027-013-0304-9

Smith SE, Read DJ. 2008. Mycorrhizal Symbiosis. New York, Academic Press

Smith FA, Smith SE. 1997. Structural diversity in (vesicular)-arbuscular mycorrhizal symbioses. New Phytologist 137: 373-388. DOI: 10.1046/j.1469-8137.1997.00848.x

Solaiman ZM, Abbott LK, Varma A. 2014. Mycorrhizal fungi: use in sustainable agriculture and land restoration. Berlin: Springer-Verlag. DOI: 10.1007/978-3-662-45370-4

Stevens KJ, Wall CB, Janssen JA. 2011. Effects of arbuscular mycorrhizal fungi on seedling growth and development of two wetland plants, Bidens frondosa L., and Eclipta prostrata (L.) L., grown under three levels of water availability. Mycorrhiza 21: 279-288. DOI: 10.1007/s00572-010-0334-2

Turner SD, Friese CF. 1998. Plant mycorrhizal community dynamics associated with a moisture gradient within a rehabilitated prairie fen. Restoration Ecology 6: 44-51. DOI: 10.1046/j.1526100x.1998.00616.x

Turner SD, Amon JP, Schneble RM, Friese CF. 2000. Mycorrhizal fungi associated with plants in ground-water fed wetlands. Wetlands 20: 200-204. DOI: 10.1672/0277-5212(2000)020[0200: MFAWPI]2.0.CO;2

Vallino M, Fiorilli V, Bonfante P. 2014. Rice flooding negatively impacts root branching and arbuscular mycorrhizal colonization, but not fungal viability. Plant, Cell \& Environment 37: 557-572. DOI: 10.1111/pce.12177

Wang Y, Li T, Li Y, Qiu Q, Li S, Guorong X. 2015. Distribution of arbuscular mycorrhizal fungi in four semi-mangrove plant communities. Annals of Microbiology 65: 603-610. DOI: 10.1007/s13213-0140896-X 
Wang Y, Li Y, Bao X, Björn LO, Li S, Olsson PA. 2016. Response differences of arbuscular mycorrhizal fungi communities in the roots of an aquatic and a semiaquatic species to various flooding regimes. Plant and Soil 403: 361-373. DOI: 10.1007/s11104-016-2811-7

Warner NJ, Allen MF, Macmahon JA. 1987. Dispersal agents of vesicular-arbuscular mycorrhizal fungi in a disturbed arid ecosystem. Mycologia 79: 721-730. DOI: 10.2307/3807824

Wolfe BE, Mummey DL, Rillig MC, Klironomos JN. 2007. Small-scale spatial heterogeneity of arbuscular mycorrhizal fungal abundance and community composition in a wetland plant community. Mycorrhiza 17: 175-183. DOI:10.1007/s00572-006-0089-y

Xu Z, Ban Y, Jiang Y, Zhang X, Liu X. 2016. Arbuscular Mycorrhizal Fungi in Wetland Habitats and Their Application in Constructed Wetland: A Review. Pedosphere 26: 592-617. DOI:10.1016/s10020160(15)60067-4 